\title{
Behavior of reinforced concrete beams reinforced with GFRP bars
}

\section{Comportamento de vigas de concreto armadas com barras de GFRP (fibras de vidro impregnadas com polímero)}
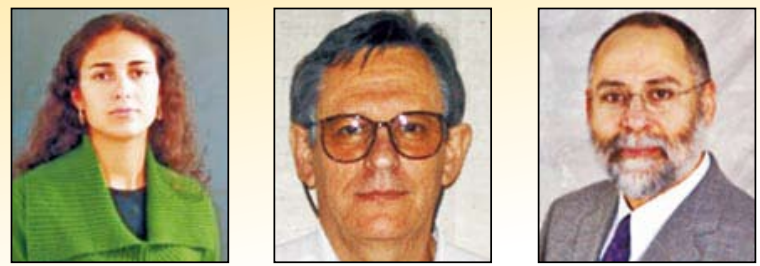

D. H. TAVARES a

danusa.tavares@usherbrooke.ca

J. S. GIONGO

jsgiongo@sc.usp.br

P. PAULTRE ${ }^{\circ}$

patrick.paultre@usherbrooke.ca

\begin{abstract}
The use of fiber reinforced polymer (FRP) bars is one of the alternatives presented in recent studies to prevent the drawbacks related to the steel reinforcement in specific reinforced concrete members. In this work, six reinforced concrete beams were submitted to four point bending tests. One beam was reinforced with CA-50 steel bars and five with glass fiber reinforced polymer (GFRP) bars. The tests were carried out in the Department of Structural Engineering in São Carlos Engineering School, São Paulo University. The objective of the test program was to compare strength, reinforcement deformation, displacement, and some anchorage aspects between the GFRP-reinforced concrete beams and the steel-reinforced concrete beam. The results show that, even though four GFRP-reinforced concrete beams were designed with the same internal tension force as that with steel reinforcement, their capacity was lower than that of the steel-reinforced beam. The results also show that similar flexural capacity can be achieved for the steel- and for the GFRP-reinforced concrete beams by controlling the stiffness (reinforcement modulus of elasticity multiplied by the bar cross-sectional area - EA) and the tension force of the GFRP bars.
\end{abstract}

Keywords: FRP, GFRP, GFRP reinforcement, flexural behavior of GFRP bars.

\section{Resumo}

As propriedades das barras de aço são causas de importantes problemas, tais como a durabilidade, ocorridos em certas estruturas de concreto armado. O uso de barras de fibras de vidro impregnadas com polímero (FRP) é uma das alternativas encontradas na literatura para essas estruturas específicas. Neste trabalho, seis vigas de concreto armado foram submetidas a ensaios de flexão em quatro pontos. Uma das vigas foi armada com aço CA-50 (viga de controle) e outras cinco foram armadas com barras de fibra de vidro impregnadas com polímero. Os ensaios foram realizados no Departamento de Engenharia de Estruturas da Escola de Engenharia de São Carlos. O programa experimental tinha por objetivo fazer uma comparação, em termos de resistência, deformação da armadura, deslocamento e alguns aspectos de ancoragem, das vigas armadas com barras de GFRP e a viga de controle armada com barras de aço CA-50. Os resultados mostraram que as vigas armadas com barras de GFRP apresentaram resistências menores do que a da viga armada com barras de aço, quando dimensionadas com os mesmos parâmetros de resistência. Além disso, foi observado que as vigas armadas com barras de GFRP podem atingir a mesma resistência à flexão da viga com barras de aço se, além da força resultante das tensões de tração nas barras também as rigidezes forem iguais, ou seja, se os produtos de inércia $E_{c} A_{c}$ forem iguais.

Palavras-chave: FRP, GFRP, barras de fibras impregnadas com polímero, barras de fibra de vidro, comportamento à flexão de vigas armadas com barras de GFRP.

a CRGP (PhD student), Département de Génie Civil, Université de Sherbrooke, danusa.tavares@usherbrooke.ca, 1200 Boul. de l'Université, Sherbrooke, Canada

${ }^{b}$ Departamento de Engenharia de Estruturas, EESC - USP, jsgiongo@sc.usp.br, Av. Trabalhador Sãocarlense 400, São Carlos, Brasil

CRGP, Département de Génie Civil, Université de Sherbrooke, patrick.paultre@usherbrooke.ca, 1200 Boul. de l'Université, Sherbrooke, Canada 


\section{Introduction}

The durability of concrete structures has always been a great concern. One of the most pressing problems in controlling durability relates to corrosion of steel reinforcement. Coastal structures, chemical industry facilities, ports, and bridges are examples of critical structures subject to reinforcement corrosion. One solution to this problem is using an alternative reinforcement material. This paper discusses the use of glass-fiber-reinforced polymer (GFRP) bars as reinforcement for concrete structures.

GFRP bars are made of composite fibers and possess numerous distinct properties such as excellent fatigue behavior, high strength-to-weight ratio, high tensile strength, and nonconductivity, while their thermal expansion is close to that of concrete. When used as reinforcement in concrete flexural elements, their tensile strength, bond properties, and elastic modulus are the main mechanical properties that govern the structural behavior of these elements.

\section{Materials and experimental program}

The test program includes six reinforced concrete beams: one control specimen reinforced with deformed steel bars and five reinforced with longitudinal GFRP bars. All beams were reinforced with steel stirrups. While the concrete and the steel properties were determined according to Brazilian codes, the material properties of the GFRP bars used in the project were taken as provided by the manufacturer. The GFRP bars (Aslam 100) were supplied by Hughes Brothers Inc.; Owens Corning Brasil provided for shipping from the United States to Brazil.

All the beam specimens were submitted to a four-point bending test. Four main aspects were examined: flexural strength, reinforcement deformation, displacement, and bonding. All beam specimens had a $150 \times 300 \mathrm{~mm}$ cross-section and a span length of $2900 \mathrm{~mm}$. Figure [1] shows details of the beam specimens.

The steel-reinforced concrete beam (V01) was designed according to the Brazilian code NBR 6118:2003 [7]. Three GFRP-reinforced concrete beams ( $\mathrm{V} 02, \mathrm{~V} 03$, and $\mathrm{V} 05$ ) were designed to have an internal ultimate tensile force $\left(A_{g} f_{u}\right)$ equal to the yield strength $\left(A_{s} f_{y}\right)$

Figure 1 - Geometry of beam specimens

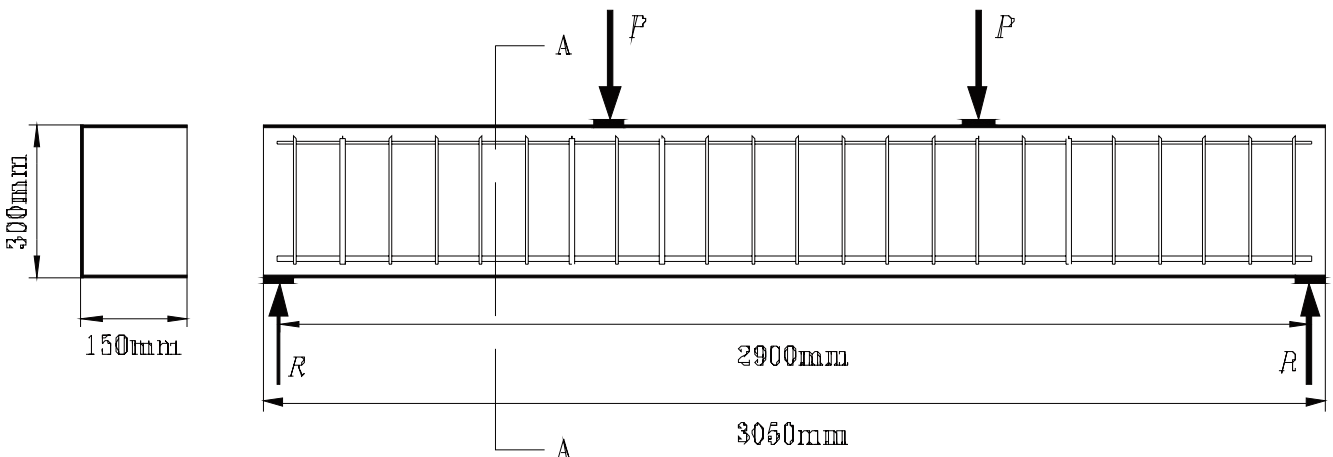

$\mathrm{A}-\mathrm{A}$

$\mathbb{P r}$ etail $\mathbb{1}$
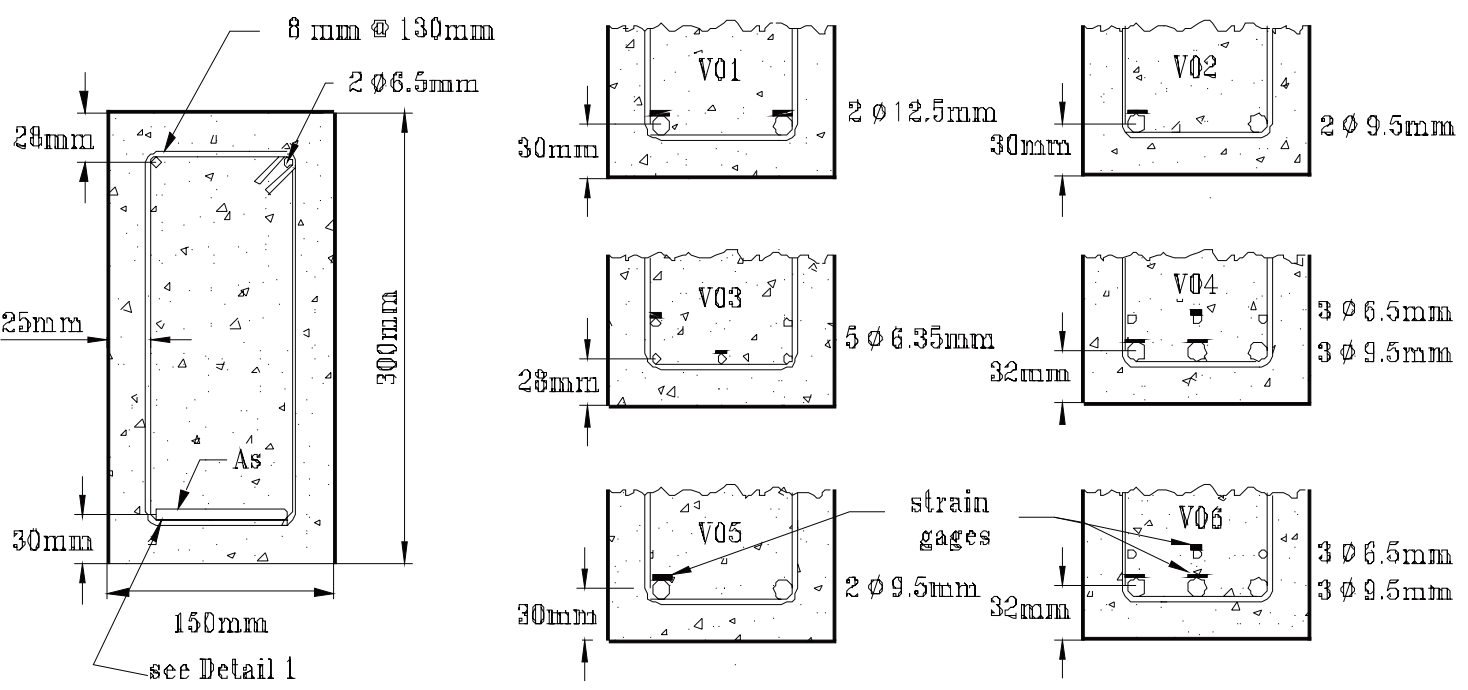


\section{Table 1 - Concrete Properties}

\begin{tabular}{cccc|} 
Mixture No. & $01-35$ days & 02-28 days & 03-14 days \\
\hline Compression Strength (MPa) & 45.98 & 44.27 & 41.95 \\
Strain at Peak (mm/m) & 1.96 & 2.03 & 1.99 \\
Tensile Strength (MPa) & 3.12 & 3.30 & 3.11 \\
Initial Tan. Elasticity Modulus (MPa) & 38791.3 & 38193.7 & 37417.2 \\
Elasticity Modulus Sec. (MPa) & 23402.8 & 21728.3 & 21059.0 \\
\hline
\end{tabular}

of specimen $\mathrm{V} 01$, where $\mathrm{A}_{\mathrm{g}}$ and $\mathrm{f}_{\mathrm{u}}$ are the total cross-sectional area and ultimate strength of the GFRP longitudinal reinforcement, and $A_{s}$ and $f_{y}$ are the total cross-sectional area and the yield strength of the steel longitudinal reinforcement, respectively. The other two GFRP-reinforced concrete beams (V04 and V06) were designed to have the same tensile force as specimen V01 but with a similar tensile limit strain of $10 \mathrm{~mm} / \mathrm{m}$ [1]. This limit strain is defined in NBR 6118:2003 [7] as the ultimate strain of the reinforcement steel bars. Thus, the test program's objective is to examine the behavior of GFRP-reinforced concrete beams designed in terms of ultimate (ELU in NBR 6118:2003 [7]) and serviceability limit states (ELS in NBR 6118:2003 [7]), corresponding to specimens V02, V03, and V05 (set 1) and to specimens V04 and V06 (set 2), respectively.

The main variables of the specimens were the diameter and anchorage of the longitudinal bars. Two 9.5-mm-diameter bars were used for specimens V02 and V05, five 6.35-mm-diameter bars were used for specimen V03, and two layers of three 9.5-mm-diameter and three $6.35-\mathrm{mm}$-diameter bars were used for specimens V04 and V06 (Figure [1]). The longitudinal bars in specimens V05 and V06 were straight, while the longitudinal bars in specimens $\mathrm{V} 02$, V03, and V04 terminated with hooks (200 mm in length).

Beam reinforcement was determined based on the $\mathrm{ACl} 440$ [1] and [2] and the fib 9.3 task group [12]. The procedure can be found elsewhere (Tavares [17] and [18]). cording to the corresponding Brazilian code: NBR 5739:1994 [5] for compressive strength, NBR 7222:1983 [6] for tensile strength (split cylinder test), and NBR 8522:1983 [3] for elastic modulus. All the concrete mixtures were defined as $1: 2.8: 3.8$, with a water/cement ratio of 0.58 and $315 \mathrm{~kg} / \mathrm{m}^{3}$ cement content. Table [1] shows the typical properties (strength, corresponding strain, elastic modulus) of the three concrete mixtures used in the experimental study. Table [1] shows that, although the testing age of the first (V01, V05) and second concrete mixtures (V02, V06) was slightly higher ( 35 days and 28 days, respectively) than the third mixture (V03, V04 - 14 days), the concrete properties of the three mixtures were comparable.

\subsubsection{Steel reinforcement}

Steel reinforcement tensile strength was determined according to Brazilian code NBR 6349:1991 [4]. Three tensile tests were made for each bar diameter: longitudinal tensile reinforcement $(12.5 \mathrm{~mm})$, longitudinal compression reinforcement $(6.35 \mathrm{~mm})$, and stirrups bars $(8 \mathrm{~mm})$.

The steel tensile tests showed that the larger the bar diameter, the more distinct the yield plateau of the steel's stress-strain behavior. Table [2] shows the characteristic properties of the steel bars used in the experimental study.

\subsection{Materials Properties}

\subsubsection{Concrete}

The designed concrete strength was $\mathrm{f}_{\mathrm{cj}}=40 \mathrm{MPa}$ and was determined using the methods of Helene and Terzian [13]. The concrete beams were cast from three concrete mixtures. For each mixture, six $100 \times 200-$ $\mathrm{mm}$ cylinders were cast. Four of these cylinders were used to determine the compressive strength and the elastic modulus; two cylinders were used to determine the tensile strength. The tests were carried out ac-

\begin{tabular}{|c|c|c|c|}
\hline \multicolumn{4}{|c|}{ Table 2 - Steel Properties } \\
\hline Diameter & & $\begin{array}{l}\text { Strength } \\
\text { (MPa) }\end{array}$ & $\begin{array}{l}\text { Corresponding } \\
\text { Strain }(\mathrm{mm} / \mathrm{m})\end{array}$ \\
\hline \multirow{2}{*}{$\Phi=6.3 \mathrm{~mm}$} & Yield & 596.21 & 4.05 \\
\hline & Failure & 606.64 & 25.94 \\
\hline \multirow{2}{*}{$\Phi=8 \mathrm{~mm}$} & Yield & 572.48 & 3.62 \\
\hline & Failure & 579.48 & 26.14 \\
\hline \multirow{2}{*}{$\Phi=12.5 \mathrm{~mm}$} & Yield & 551.81 & 3.48 \\
\hline & Failure & 579.08 & 26.60 \\
\hline
\end{tabular}

\subsubsection{GFRP reinforcement}

GFRP reinforcement tensile tests were conducted at the EESC laboratory, but the results were inconclusive. Further tests are needed in order to establish the proper test procedure at the EESC laboratory. Therefore, the main properties of the GFRP bars $(9 \mathrm{~mm}$ and $6 \mathrm{~mm}$ ) used in the test program were provided by the manufacturer. Table [3] shows these properties (provided by the manufacturer, Hughes Brothers, Inc. [14]). GFRP bars have a characteristic linearelastic behavior up to failure. 


\subsection{Test setup and instrumentation}

The specimens were basically constructed as follows (Figure [2]): construction of the wood framework, construction of the reinforcement cage, placement of the reinforcement cage, and casting, curing, and transporting the concrete for storage until the time of testing. Due to lack of experience, the application of the unconventional GFRP bars was not trivial. The main problem found concerns the weight of the steel stirrups, which was relatively high and induced a small deformation of the GFRP bars prior to casting of the specimens.

Four-point bending tests were conducted to examine the flexural behavior of the steel and the GFRP-reinforced concrete beams. The test setup is presented in Figure [3] (for further information see Takeya [16]). Neoprene layers were placed on each support and the forces were manually applied by a hydraulic system and jacks. Longitudinal steel strains were measured by electrical resistance strain gages; their locations in the specimens can be seen in Figure [1]; each monitored bar had three strain gages: at the center and both ends of the bars. The displacements at the mid-span and at the supports were measured using linear variable differential transformers (LVDTs). The LVDTs were located as shown in Figure [4].

\section{Figure 2 - Steps in constructing specimens}

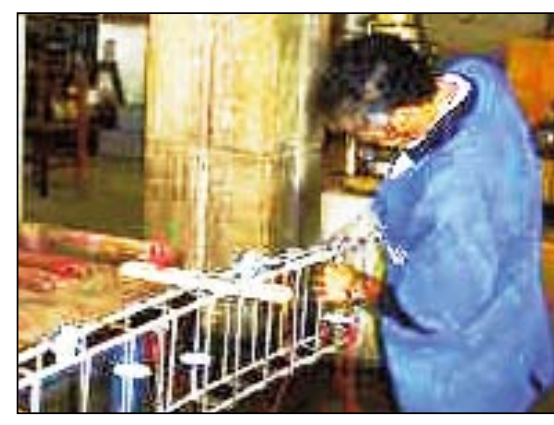

Longitudinal reinforcement placement

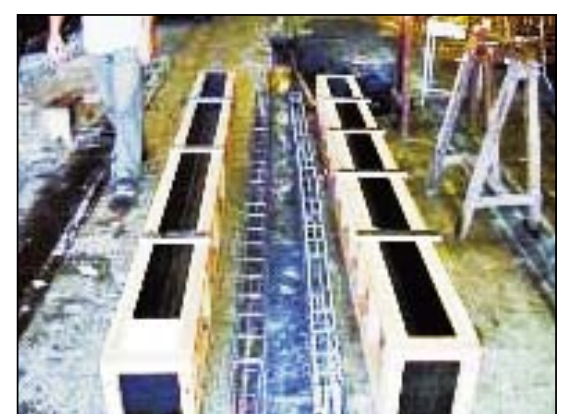

Frameworks and reinforcement cages

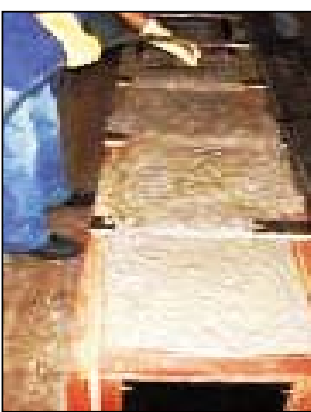

Concrete casting

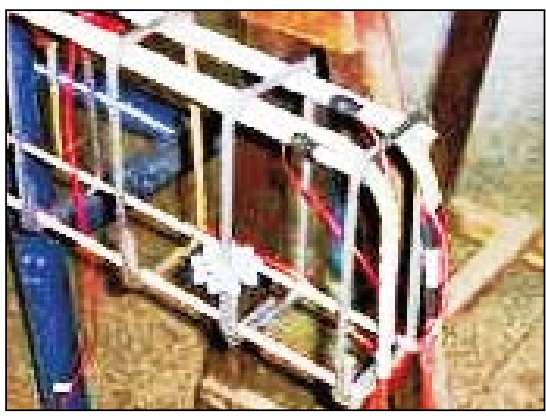

Placement of steel stirrups
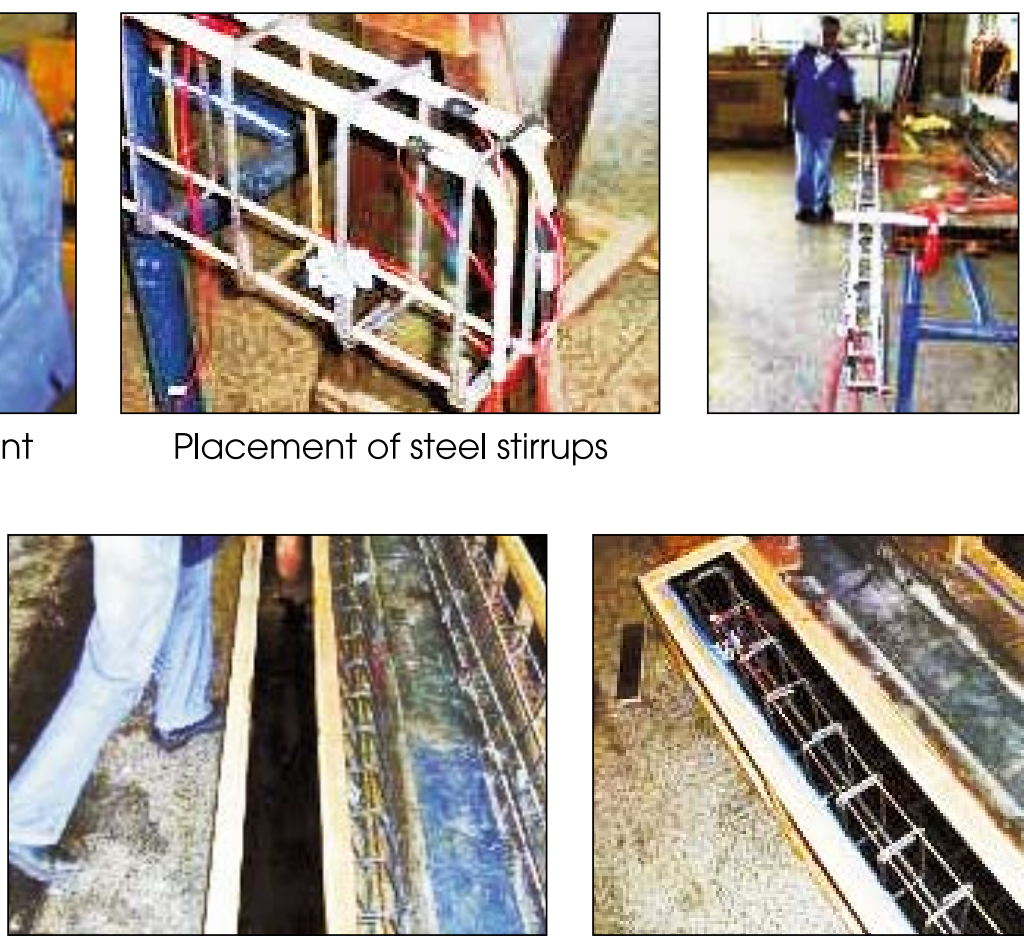

Oil aplication

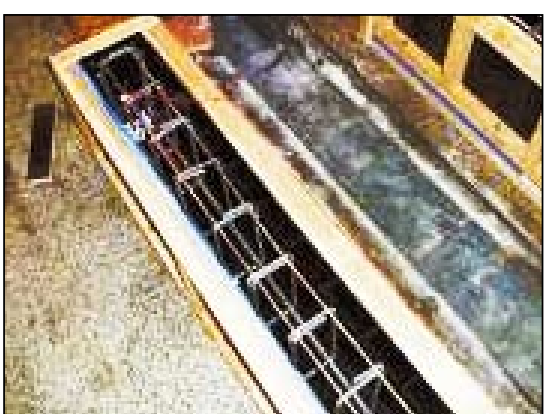

Beam ready to be cast

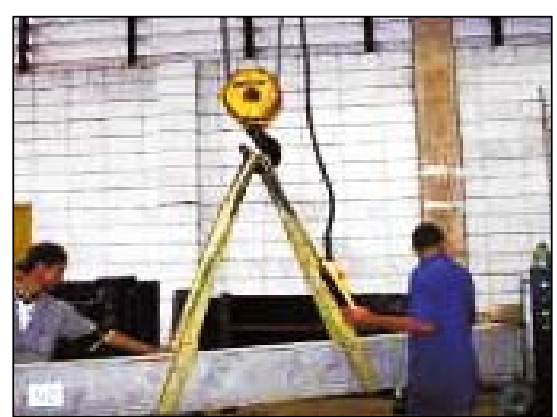

Transport of the beam

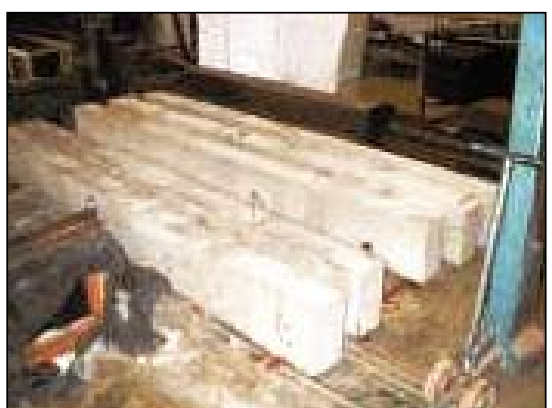

Storage 


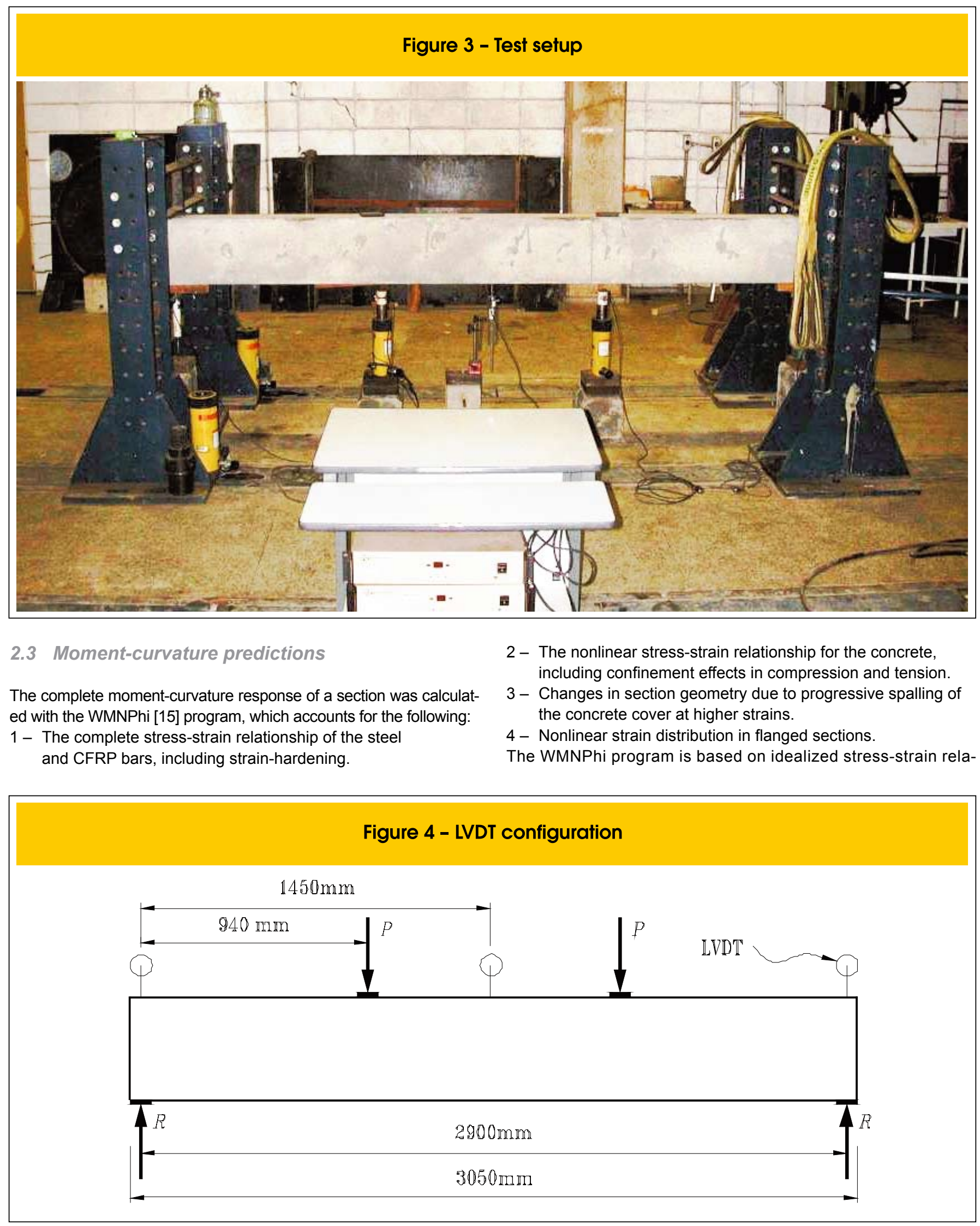


tionships for the materials and ensures compatibility of strains and equilibrium of forces. In order to predict the response, the cross-section of a member is divided into a number of concrete strips, each divided into confined and unconfined portions. This makes it possible to model the beneficial effects of confinement in the confined region of each strip. Concrete is assumed to spall at a strain of -0.004 , but it can be set independently. As shown in Figure [5]f, the compressive stress-strain relationship of the concrete depends on the degree of confinement. The steel or GFRP bars are modeled as concentrated areas located at the appropriate positions in the cross-section. The stress-strain for steel bars includes strain hardening, while it is linear for the GFRP bars. The effect of tension stiffening in the concrete after cracking is accounted for in specified concrete layers. The average tensile stress in the concrete after cracking is as given by Vecchio and Collins [19] and is shown in Figure [5]g. In addition, WMNPhi incorporates stress-strain relationships that include bilinear elastoplastic, trilinear, and inverse Ramberg-Osgood relationships for modeling highly curved stress-strain relationships.

The analysis procedure is as follows:

1 - Assume a top fiber strain.
2 - Assume the value of the depth to the neutral axis.

3 - Compute all stress resultants in the concrete and steel or GFRP for the assumed strain distribution and accounting for concrete-cover spalling.

4 - Iterate on the depth to the neutral axis until equilibrium is satisfied to a specified accuracy.

5 - Calculate the resultant moment, axial load, and curvature.

6 - Increment the top fiber strain and repeat steps 2 to 5 .

The moment-curvature curves for the specimens were obtained with WMNPhi. Four different models were used: one for the steel-reinforced beam (V01) and three for the GFRP-reinforced beams (V02/V05, V03, and V04/V06). The stress-strain behavior of the steel was defined with strain-hardening. The composite rebar stress-strain behavior was linear up to ultimate stress. The peak stress and corresponding strain of the concrete were defined by the cylinder tests; the concrete stress-strain curve used was parabolic for compression and followed the Vechio \& Collins stress-strain curve in tension. Tension stiffening in the concrete was considered. The stiffened area was defined with a height of $110 \mathrm{~mm}$ from the bottom tension fiber. This height was found using a combination of the procedures from the CEB/FIP MC90 [10] Equation [1] and CEB/FIP 1978 [9] Equation [2]:

\section{Figure 5 - WMNPhi calculation procedure}
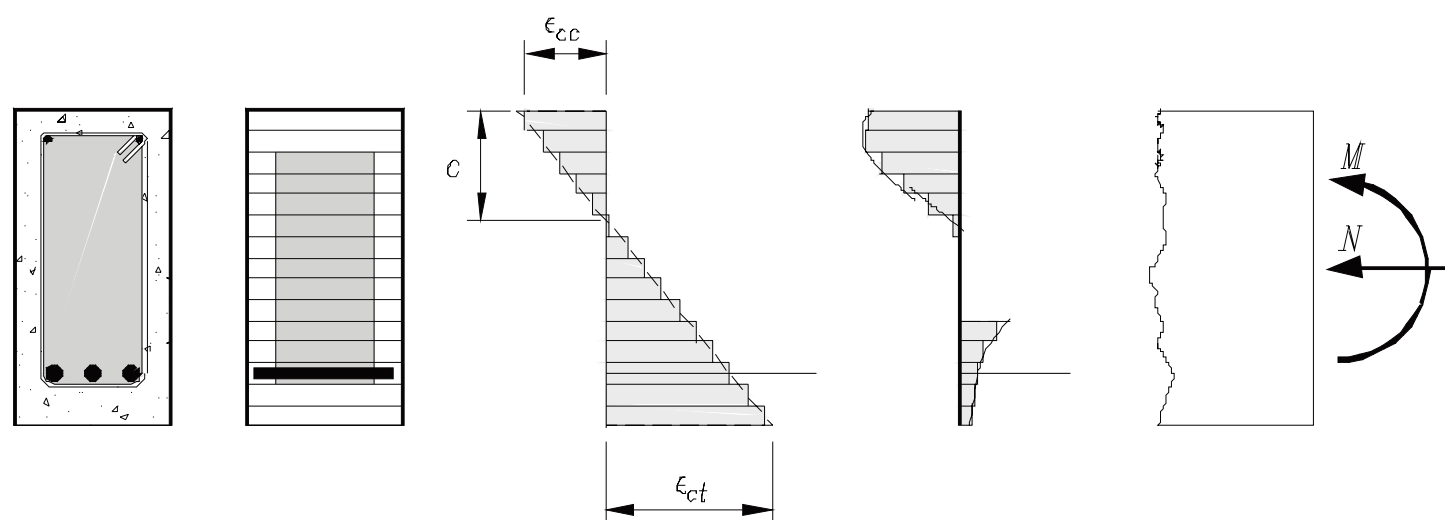

(a) Section (b) Idealization

(c) Strains

(d) Stresses

(e) Resulting Forees

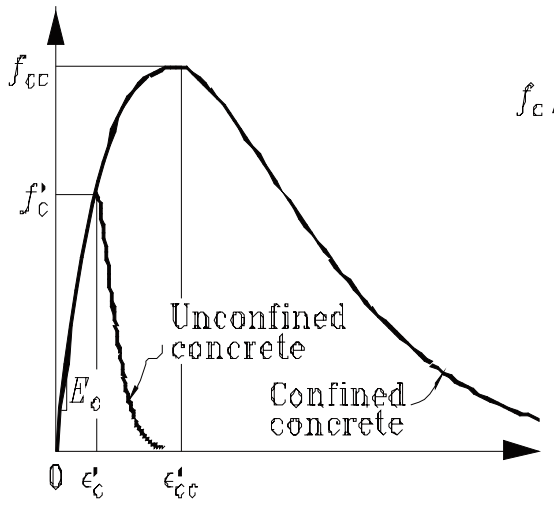

(1) Concrete in Compression

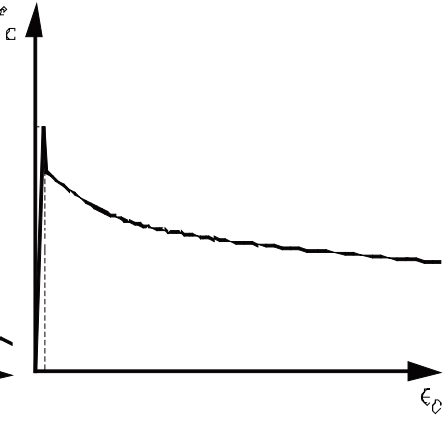

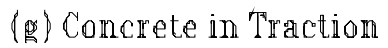

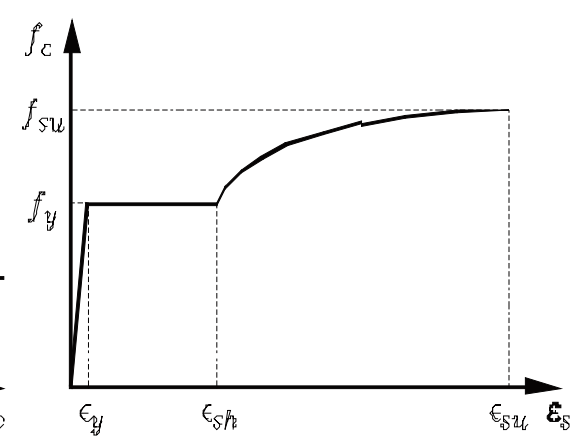

(1) Steel in Traction on Compressum 


$$
h_{\text {stiff }}=2.5 \cdot c>\frac{h-c}{3}
$$

$$
h_{\text {stiff }}=c+d_{l}+1 / 2 \cdot d_{b}+7.5 d_{b}
$$

Where:

$c=$ concrete cover

$d_{l}=$ lateral reinforcement diameter

$d_{b}=$ longitudinal reinforcement diameter

Even though these procedures are applied for steel-reinforced concrete beams, Ferracuti and Savoia [11] and Bischoff and Paixao [8] showed that they can also be applied to FRP-reinforced beams.

\subsubsection{Analytical force-displacement curves}

In order to verify if the curves obtained in WMNPhi agreed well with the experimental results, the analytical force-displacement curves were calculated as detailed below.

For a reinforced concrete beam, the midspan deflections can be obtained after defining the moment-curvature relationship from the section layer-by-layer analysis. Figure [6] describes this procedure. Due to symmetry, the calculations were made on only half of the beam. The part of the beam with a linear variation of moment (between the support and the applied load) was divided into 9 elements, each having a width of $0.10 \mathrm{~m}$. One element was used in the pure moment region. The reactions at both ends of the beam can be expressed as:

$$
F=\frac{M}{0.94}
$$

It was also possible to determine the moments all along the element by the relation:

$$
M_{j}=F x_{j}
$$

where $x_{j}$ is the coordinate of the section from the support. Each value of moment has a corresponding curvature value from the moment-curvature curve, so, by interpolation, it was possible to describe the element curvature. The midspan displacement can be calculated as:

$$
\delta=\int_{0}^{L / 2} \varphi \cdot x \cdot d x=\sum_{j=1}^{11}\left(\varphi_{j} x_{j}+\varphi_{j-1} x_{j-1}\right) \frac{\Delta_{x}}{2}+\varphi \cdot(0.94 \cdot 2) \cdot \frac{0.51}{8}
$$

where $\varphi_{j}$ is the curvature corresponding to the moment at the coordinate $x_{j}$. If this procedure is repeated for a large number of moment points, the force-displacement curve can be defined. The moment values were calculated for each step of the experimental applied forces.

\section{Results and discussions}

Figure [7] shows the experimental force versus longitudinal reinforcement strain curves for the six specimens. The reported average longitudinal tensile strains were taken from the average of the strain gages placed at the lowest reinforcement layer of the beam cross-section and the force presented is the resultant of the two applied loads. Specimen flexural failure was due to concrete compressive crushing (specimens V01 after steel yielding, V04 and V06) or to the rupture of the GFRP bars (GFRP-reinforced beams, V02, V03, and V05). These behaviors can also be detected from the curves in Figure [7].

Concrete cracking was identified in all specimens at a load level of about $20 \mathrm{kN}$, after which the steel reinforcement maintains an almost linear strain increase until yielding. Figure [7] shows that the strains at failure in the GFRP bars are greater than the strain obtained in the steel reinforcement bars in the control beam. It is furthermore important to point out the high deformation capacity of the GFRP bars, which reached the limit of $10 \mathrm{~mm} / \mathrm{m}$ strain (given

\section{Figure 6 - Discretization for determination of displacement responses}

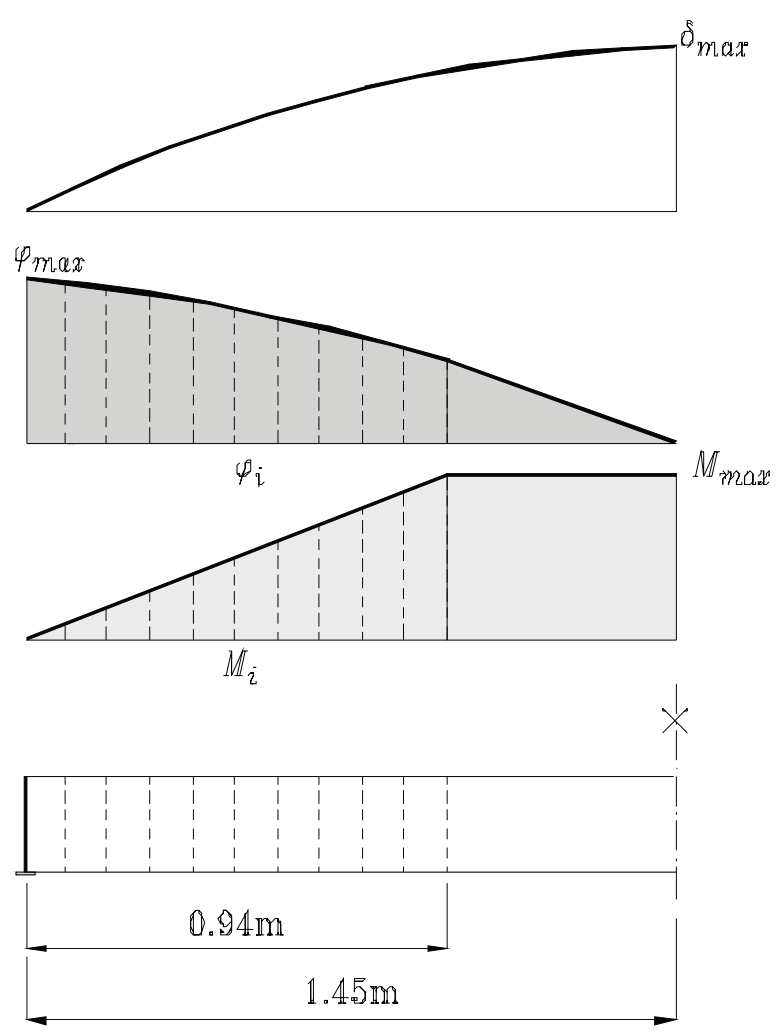


by NBR 6118:2003 for steel reinforcement) before the failure deformation.

Another important aspect of the experimental test results is the crack pattern of the concrete beams, as shown in Figure [8]. The cracks pattern in the steel-reinforced beam (Figure [8]a), shows less cracking than that developed in the GFRP-reinforced beams. Moreover, the number of bars is definitely one variable to be taken into account in controlling the concrete cracking. Figure [8]b and Figure [8]c show the crack patterns of the specimens reinforced with 2 (V02 and V05) and with 5 (V03) longitudinal GFRP bars.

\section{Figure 7 - Force - Reinforcement strain responses}
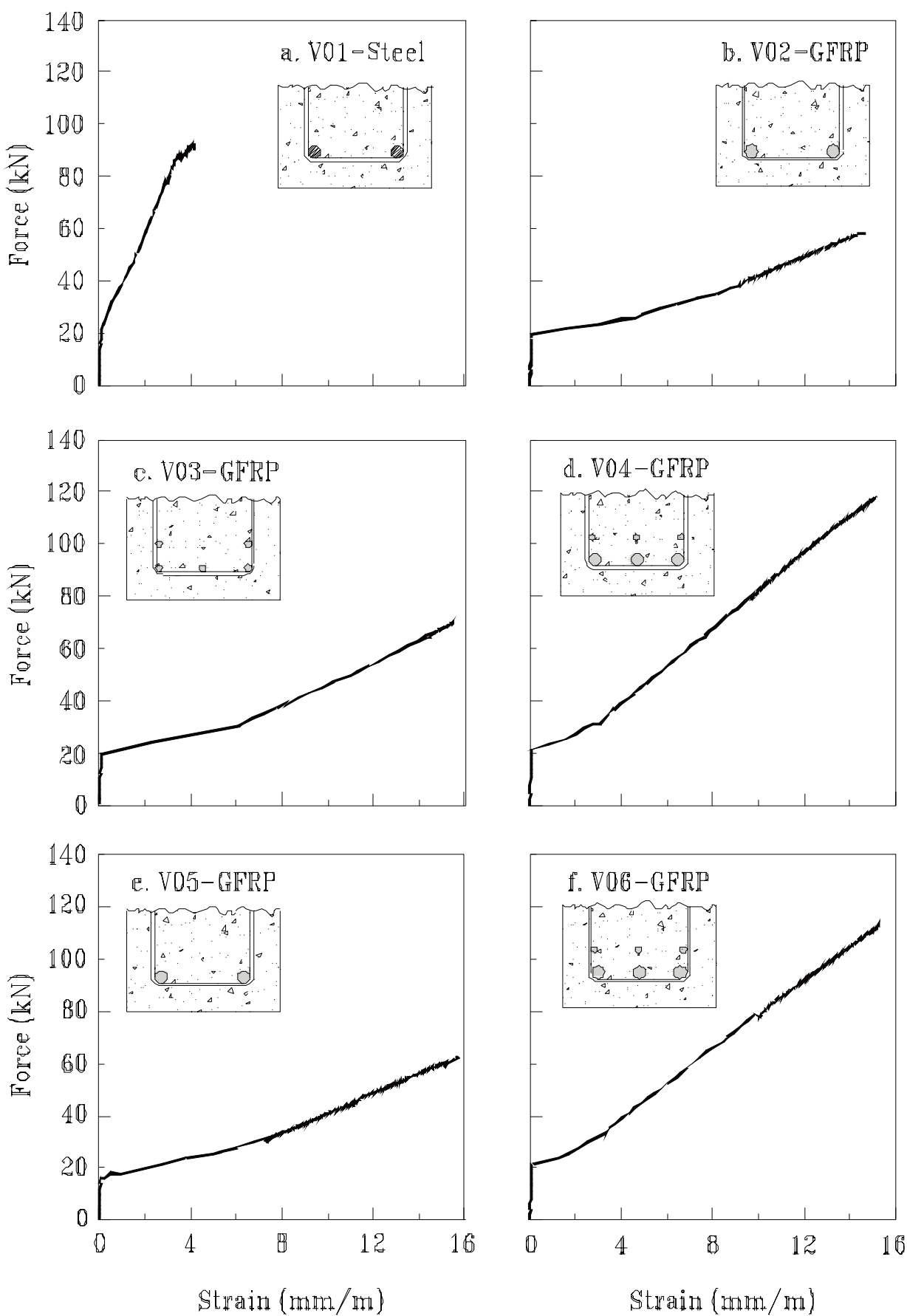


\section{Figure 8 - Beam cracking pattern}

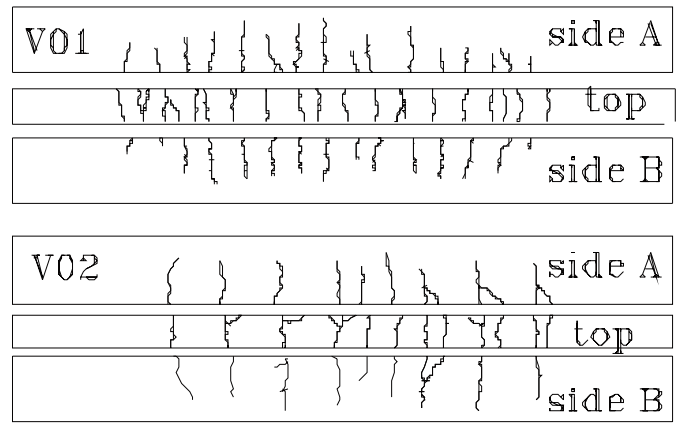
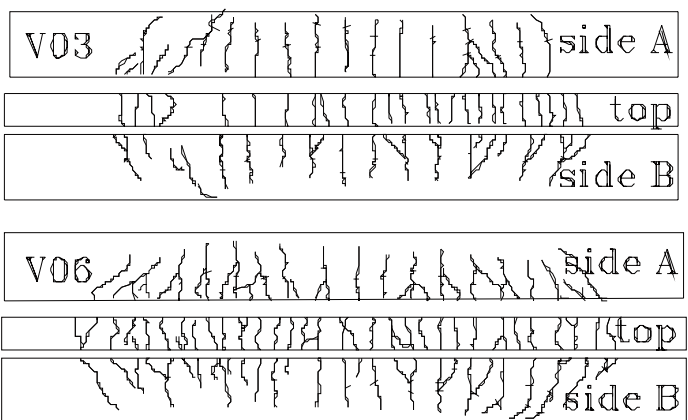

Besides their close reinforcement area values, the number of reinforcement bars plays an important role controlling the cracks distribution. The beams designed with smaller diameter reinforcement GFRP bars (V04 and V06) showed a pattern of smaller and more distributed cracks along the elements (Figure [8]d).

\subsection{Moment - curvature curves}

Although the force-displacement behavior of the beams was experimentally measured, the beam moment-curvature curves could not be derived. Therefore, an analysis was conducted using the WMNPhi (Paultre [15]) computer program with a layer-by-layer analysis. Using the material properties obtained from standard tests (concrete tensile and compressive strength and elastic modulus; steel tensile

\section{Figure 9 - Moment-curvature response curve}

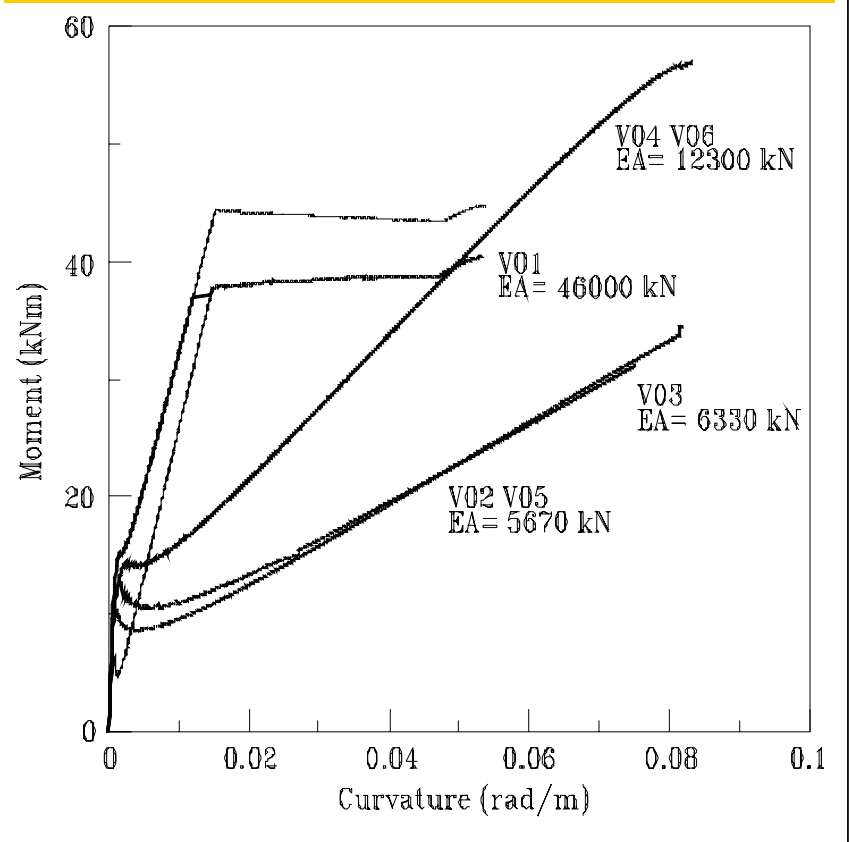

strength and elastic modulus), it was possible to analytically determine the moment-curvature curves of the beam specimens.

Figure [9] describes the moment-curvature curves obtained from WMNPhi for the six specimens. Note that the curve for the steel-reinforced concrete beam was derived from two analyses to account for the concrete tension stiffening effect up to the longitudinal steel yielding (see Figure [9]). Figure [9] shows that the main parameter controlling the behavior of the reinforced concrete beams is the longitudinal reinforcement stiffness, EA. The specimens designed in terms of serviceability limit state (V04, and V06) achieved the flexural capacity of the steel-reinforced concrete beam at a lower curvature than the specimens designed in terms of ultimate limit state (V02, V03, and V05).

The objectives of the GFRP specimens were partially reached. The GFRP-reinforced beams that were designed in terms of ultimate limit state failed to reach a flexural capacity similar to that of the steel-reinforced beam $(42.43 \mathrm{kNm})$. The experimental results show that specimens $\mathrm{V} 02, \mathrm{~V} 03$, and $\mathrm{V} 05$ achieved maximum capacity of $27.23 \mathrm{kNm}, 31.58 \mathrm{kNm}$, and $31.17 \mathrm{kNm}$.

Although it is clear that the design procedures used in this project were not able to ensure a determined flexural capacity, it is also known that elements reinforced with GFRP bars are more likely to be designed for serviceability limit state instead of ultimate limit state.

\subsection{Force-displacement analytical curves}

To compare the experimental with the analytical results, the analytical moment-curvature curves were integrated to give force-displacement response curves. Figure [10] describes the analytical and the experimental results.

The values obtained from WMNPhi are more conservative than those obtained from the experimental tests. Although the experimental and analytical results are not identical, they agree sufficiently well to confirm reliable reproduction of the behavior of the GFRP-reinforced concrete specimens with WMNPhi.

\section{Conclusions}

This paper presents experimental study performed at the EESC to investigate the flexural behavior of GFRP-reinforced concrete beams. The results show that the relatively low modulus of elastic- 
ity and the high GFRP rupture strain are the main variables that influence the flexural behavior of the GFRP-reinforced concrete beams. Besides, the difference in the material stress-strain behavior of the elastic-plastic steel and the linear-elastic GFRP results in a different overall behavior of the GFRP-reinforced concrete beams compared to the steel-reinforced concrete beams. It has been shown that controlling the reinforcement stiffness and the maximum internal tension force can yield an appropriate flexural behavior of the GFRP-reinforced concrete beams.

Due to the sudden failure defined by the rupture of the GFRP

\section{Figure 10 - Analytical and experimental force-displacement of beam responses}
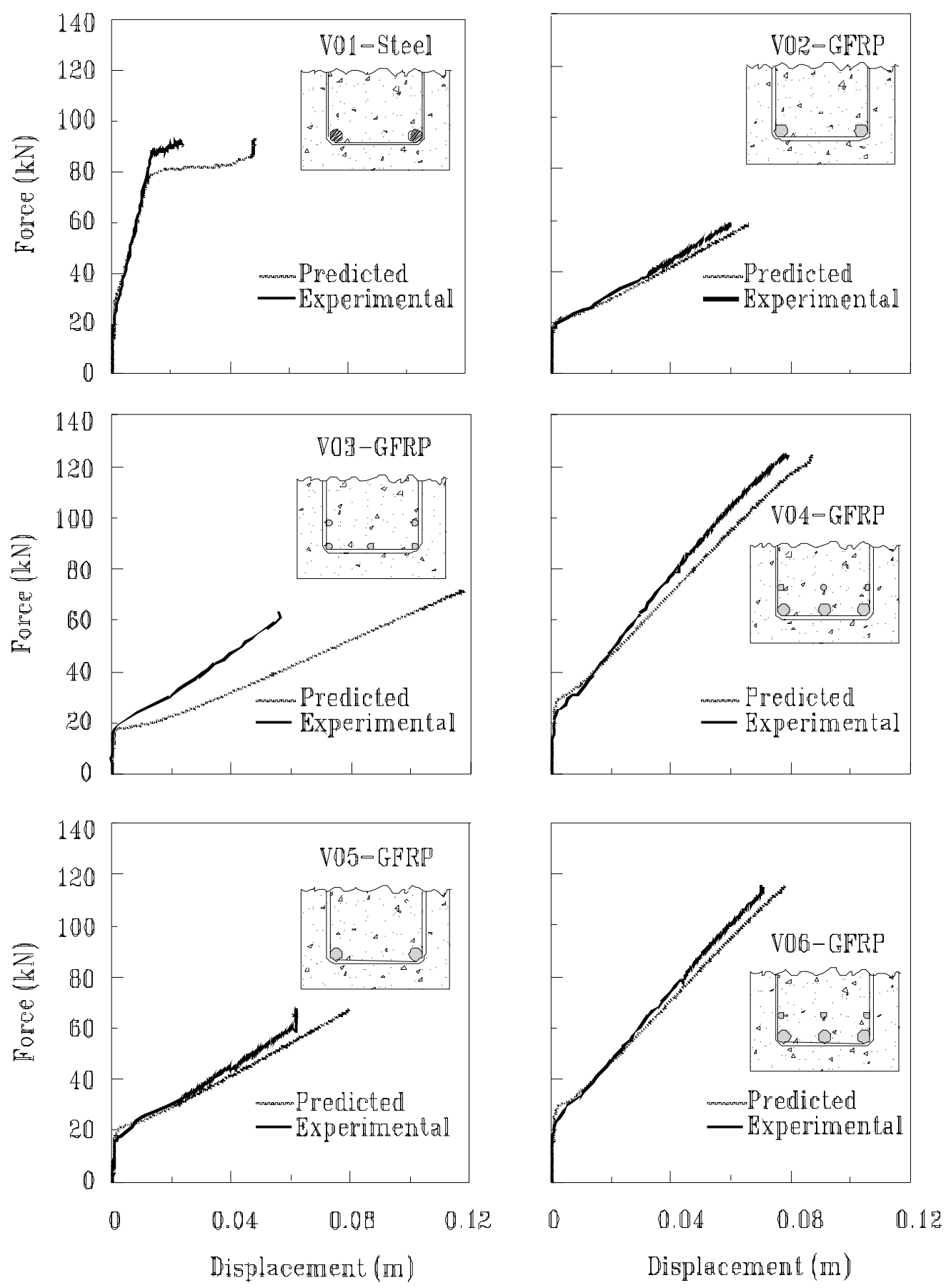
bars, the ACI 440.1R committee (2003) [2] has already suggested forcing the concrete crushing failure by designing over-reinforced GFRP-reinforced concrete elements.

For the purpose of designing GFRP-reinforced concrete elements, most of the available design codes have adapted the design principles for steel-reinforced concrete, which are mostly based on ultimate limit state, followed by a verification of serviceability limit state. This study shows that it is more appropriate to design GFRPreinforced concrete beams based on the combination of serviceability and ultimate limit states.

This project is one of several studies needed to provide the Brazilian construction industry with a new reliable structural reinforcement material. These studies will have to focus on enhancing design procedures to achieve better flexural behavior of GFRP-reinforced concrete based on serviceability and ultimate limit states. Moreover, more research studies are needed to investigate the effect of shear and bonding stresses on the behavior of the GFRPreinforced elements. Another issue to be examined is the use of GFRP bars in prestressed elements.

\section{References}

[01] American Concrete Institute (1996) ACl Committee 440R State-of-Report on Fiber Reinforced Plastic (FRP) Reinforcement for Concrete Structures.

[02] American Concrete Institute (2003). ACl Committee 440.1R Guide for the Design and Construction of Concrete Reinforced with FRP Bars.

[03] Associação Brasileira De Norma Técnicas (1984). NBR 8522:1884 - Concreto - Determinação do módulo de deformação estática e diagrama tensão deformação - Método de ensaio. Rio de Janeiro.

[04] Associação Brasileira De Norma Técnicas (1991). NBR 6349:1991 - Fios, barras e cordoalhas de aço para armaduras de protensão - Ensaio de tração Método de ensaio. Rio de Janeiro.

[05] Associação Brasileira De Norma Técnicas (1994). NBR 5739:1994 - Concreto - Ensaio de compressão de corpos-de-prova cilíndricos - Método de ensaio. Rio de Janeiro.

[06] Associação Brasileira De Norma Técnicas (1994). NBR 7222:2003 - Argamassa e concreto Determinação da resistência à tração por compressão diametral de corpos-de-prova cilíndricos - Método de ensaio. Rio de Janeiro.

[07] Associação Brasileira De Norma Técnicas (2003). NBR 6118:2003 - Projeto de estruturas de concreto. Rio de Janeiro.

[08] Bischoff, P. H. and Paixao R. (2004) Tension stiffening and cracking of concrete reinforced with glass fiber reinforced polymer (GFRP) bars. Canadian Journal of Civil Engineering - number 31: pages 579-588.

[09] CEB-FIP, Model Code 1978 for Concrete Structures: CEB-FIP International recommendations $3^{\text {rd }}$ edition, Comité Euro-International du Béton, Paris, France, 1978.

[10] CEB-FIP, Model Code 1990 for Concrete Structures: CEB-FIP International recommendations, Comité Euro-International du Béton, Lausanne, Switzerland, 1993.
[11] Ferracuti B. and Savoia M. (2005) Tension Stiffening Law For FRP - Reinforced Concrete Elements under Service Loadings. Proceedings of the International Symposium on Bond Behaviour of FRP in Structures (BBFS 2005) at 2005 International Institute for FRP in Construction pages 221-228.

[12] Fib Task Group 9.3. FRP (Fibre Reinforced Polymer) Reinforcement for Concrete Structures (draft).

[13] Helene, P/ R.L. \& Terzian, P. R. (1993). Manual de Dosagem e Controle do Concreto. $1^{\text {a }}$ reimpressão (maio 95). São Paulo, PINI / SENAI.

[14] Hughes Bros. Inc. (2001). Mechanical Properties of GFRP rebar. Seward, NE. http://www.hughesbros.com

[15] Paultre, P. (2001). WMNPHI -- A program for sectional analysis of structural concrete -- User manual, Centre de recherche en génie parasismique et en dynamique des structures, Université de Sherbrooke, QC, Canada, Report CRGP-2001/01.

[16] Takeya, T. (2000). Exemplo de ensaio de uma viga de concreto armado simplesmente apoiada. EESC-USP.

[17] Tavares, D. H. (2006). Análise teórica e experimental de vigas de concreto armadas com barras não metálicas de GFRP. Dissertação de Mestrado. EESC - USP, São Carlos.

[18] Tavares, D. H., Ferreira O. P., and Giongo J. S. (2006). Propriedades e dimensionamento de estruturas de concreto armadas com barras não metálicas de GFRP. IBRACON, $48^{\circ} \mathrm{CBC}$. Rio de Janeiro.

[19] Vecchio, F.J. and Collins, M.P., The modified compression field theory for reinforced concrete elements subjected to shear, $\mathrm{ACl}$ Journal, Proceedings, V. 83, No. 2, March-April 1986, 219-231. 